\title{
Pengembangan Lembar Kerja Siswa Berbasis Group Investigation untuk Memfasilitasi Kemampuan Penalaran Matematis Siswa SMP
}

\author{
Mirse Ayurila ${ }^{1}$, Risnawati $^{2}$, Erdawati Nurdin ${ }^{3}$ \\ Jurusan Pendidikan Matematika, Universitas Islam Negeri Sultan Syarif Kasim Riau \\ Email: mirse.ayurila@student.uin-suska.ac.id ${ }^{1}$,erdawati.nurdin@uin-suska.ac.id ${ }^{3}$
}

\begin{abstract}
Abstrak. Penelitian ini mengembangkan suatu media pembelajaran berupa lembar kerja siswa berbasis group investigation. Pengembangan LKS berbasis Group Investigation ini bertujuan untuk memfasilitasi kemampuan penalaran matematis siswa pada materi segitiga. Model pengembangan yang diterapkan adalah model ADDIE. Subjek penelitian ini adalah siswa kelas VII.8 SMPN 4 Siak Hulu, yang berjumlah 35 orang. Pengumpulan data dilakukan menggunakan angket dan tes. Analisis terhadap data yang diperoleh dari angket menunjukkan bahwa LKS berbasis Group Investigation telah valid dan praktis untuk digunakan. Hasil uji t menyimpulkan bahwa LKS ini efektif untuk memfasilitasi kemampuan penalaran matematis siswa. LKS berbasis Group Investigation ini dapat digunakan sebagai media pembelajaran bagi siswa kelas VII pada materi segitiga.
\end{abstract}

Kata Kunci: LKS, Kemampuan Penalaran Matematis, Model Pengembangan ADDIE, Group Investigation, segitiga.

\section{PENDAHULUAN}

Salah satu tujuan pembelajaran matematika adalah mengembangkan kemampuan penalaran matematis siswa. Hal ini tercantum dalam Permendikud nomor 21 tahun 2016 tentang standar isi pendidikan dasar dan menengah mengenai tujuan pembelajaran matematika tingkat pendidikan dasar (kelas VII-IX) yang salah satunya adalah siswa mampu mengidentifikasi pola dan menggunakannya untuk menduga perumuman/aturan umum dan memberikan prediksi (Permendikbud, 2016:117).

Materi matematika dan penalaran matematika merupakan dua hal yang tidak dapat dipisahkan, yaitu materi matematika dipahami melalui penalaran, dan penalaran dipahami dan dilatihkan melalui belajar materi matematika, sehingga kemampuan penalaran matematis sangat penting dan dibutuhkan dalam mempelajari matematika. Pembelajaran matematika di sekolah harus dapat menyiapkan siswa untuk memiliki kemampuan penalaran matematis sebagai bekal untuk menghadapi tantangan perkembangan dan perubahan. Kemampuan penalaran matematis diperlukan siswa baik dalam proses memahami matematika itu sendiri maupun dalam kehidupan sehari-hari (Mikrayanti, 2016:98). Terlebih dalam kehidupan sehari-hari, kemampuan bernalar berguna pada saat menyelesaikan permasalahan-permasalah sehari-hari. Oleh karena itu, melatih cara berpikir dan bernalar dalam memahami permasalahan agar dapat menarik kesimpulan dengan baik sangatlah penting.

Berdasarkan observasi yang peneliti lakukan di SMP Negeri 4 Siak Hulu, tampak bahwa. masih sedikit siswa yang mampu menyelesaikan permasalahan matematika yang diberikan. Banyak siswa belum dapat memberikan penjelasan mengenai alasan atau bukti dari permasalahan matematika yang diberikan terhadap jawaban yang dimiliki, belum dapat menemukan cara atau 
langkah-langkah penyelesaian yang tepat untuk menyelesaikan permasalahan matematika serta belum dapat menentukan pola sifat atau gejala matematika untuk membuat generalisasi. Kesalahan tersebut hampir dilakukan oleh seluruh siswa. Hal ini memberikan informasi rendahnya kemampuan penalaran matematika.

Salah satu faktor yang mungkin menjadi penyebab rendahnya kemampuan penalaran matematis siswa adalah belum tersedianya media khusus yang digunakan untuk proses pembelajaran terutama untuk memfasilitasi kemampuan penalaran matematis siswa. Media pembelajaran yang digunakan selama ini dibuat oleh penerbit, sehingga cenderung tidak inovatif, kurang menarik dan tidak adanya ruang bagi siswa untuk mengkostruksikan ide-ide matematis mereka sehingga siswa bosan dan mengurangi keaktifan belajar.

Menyikapi rendahnya kemampuan penalaran matematis siswa, maka pendidik sebagai salah satu faktor keberhasilan dalam pembelajaran harus mengupayakan peningkatan kualitas pembelajaran. Diantaranya dengan menyediakan media pembelajaran yang berkualitas dan bisa meningkatkan kemampuan penalaran matematis siswa. Penggunaan media pembelajaran yang tepat dalam pembelajaran dapat meningkatkan pemahaman, minat dan motivasi peserta didik dalam belajar. Media pembelajaran juga dapat membantu peserta didik meningkatkan pemahaman, menyajikan data dengan menarik dan terpercaya, memudahkan penafsiran data dan memadatkan informasi (Arsyad, 2014:20).

Saat ini banyak sekali media pembelajaran yang telah digunakan oleh guru, seperti LKS (Lembar Kerja Siswa), modul, hand out, buku dan lain-lain. Media pembelajaran ini haruslah disesuaikan dengan kebutuhan siswa sehingga dapat mencapai tujuan pembelajaran yang diharapkan. Untuk itu, perlu dikembangkan suatu media yang disesuaikan dengan kebutuhan siswa dan tujuan pembelajaran yang diharapkan.

Berdasarkan observasi yang dilakukan di SMP Negeri 4 Siak Hulu, peneliti menemukan bahwa siswa di SMP tersebut memerlukan media pembelajaran yang dapat mendorong mereka untuk aktif, membimbing siswa mengkonstruksi pemahamannya sendiri dan akhirnya dapat memfasilitasi kemampuan penalaran siswa. Salah satu media pembelajaran yang dapat digunakan untuk mencapai tujuan tersebut adalah lembar kerja siswa (LKS). LKS atau bahan ajar cetak berupa lembar-lembar kertas yang berisi materi, ringkasan, dan petunjuk-petunjuk pelaksanaan tugas pembelajaran yang harus dikerjakan oleh siswa, yang mengacu pada kompetensi dasar yang harus dicapai (Prastowo, 2013:203).

Untuk menunjang kemampuan penalaran siswa, tentunya LKS yang ditulis haruslah memuat petunjuk-petunjuk tugas yang dapat mengarahkan siswa untuk bernalar. Oleh sebab itu, LKS ini harus dibuat mengikuti langkah-langkah model, strategi atau pendekatan yang membimbing siswa untuk aktif dan mengarahkan siswa untuk membangun pemahamannya sendiri. Salah satu model pembelajaran yang melibatkan siswa aktif adalah Group Investigation. Pembelajaran kooperatif tipe Group Investigation merupakan salah satu model pembelajaran kooperatif yang menekankan pada partisipasi dan aktivitas siswa untuk mencari sendiri materi (informasi) pelajaran yang akan dipelajari melalui bahan-bahan yang tersedia. Siswa dilibatkan sejak perencanaan, baik dalam menentukan topik maupun cara untuk mempelajarinya melalui investigasi. Group Investigation melatih siswa untuk menumbuhkan kemampuan berfikir mandiri, mengunakan kemampuan penalaran untuk memahami konsep yang dipelajari, serta menemukan pola atau sifat dari gejala matematis untuk membuat generalisasi, berkesempatan untuk berdiskusi dengan teman, berntanya dan membagi pengetahua yang diperoleh pada lainnya (Sari, Yerizon dan ZA, 2012:42).

Memperhatikan kebutuhan siswa terhadap suatu media pembelajaran yang mampu memfasilitasi kemampuan penalarannya dan keunggulan model pembelajaran Group Investigation, maka peneliti bermaksud mengembangkan media pembelajaran berupa lembar kerja siswa (LKS) berbasis Group Investigation untuk memfasilitasi kemampuan penalaran siswa SMP. 


\section{METODE}

Penelitian ini bermaksud mengembangkan suatu produk, maka penelitian ini termasuk ke dalam penelitian dan pengembangan (research and development). Terdapat beberapa model pengembangan, yaitu model 4D, model ASSURE, model Dick and Carry, model ADDIE, model Smith and ragan, model Plom dan model lainya. Desain pengembangan yang digunakan adalah model ADDIE. Model ADDIE merupakan model yang sering digunakan dalam penelitian dan pengembangan bahan ajar seperti LKS, modul, dan buku ajar (Mulyatiningsih, 2012 :195). Model ADDIE memiliki lima fase atau tahap yang dilakukan secara sistemik dan sistematik. Sesuai dengan namanya yaitu (A)nalyze, (D)esign, (D)evelopment, (I)mplementation, dan (E)valuation (Pribadi, 2009:125).

Adapun tahapan-tahapan penelitian dan pengembangan yang dilakukan adalah :

1. Melakukan analisis kebutuhan untuk menentukan masalah dan solusi yang tepat.

2. Membuat perencanaan dengan menentukan kompetensi yang ingin dicapai serta pendekatan/model pembelajaran yang akan dimuat di dalam LKS.

3. Menyusun LKS sesuai kompetensi yang diharapkan dan model pembelajaran Group Investigation.

4. Memvalidasi LKS yang telah disusun dan merevisi sesuai saran validator.

5. Melakukan ujicoba LKS di kelompok kecil, yang terdiri atas 6 siswa dan merevisi sesuai hasil ujicoba.

6. Melanjutkan uji coba ke lapangan, dengan kelompok terbatas untuk melihat kepraktisan LKS. Uji kelompok terbatas ini di lakukan di kelas VII.8 SMPN 4 Siak Hulu.

7. Melakukan uji efektifitas penggunaan LKS, dengan membandingkan rata-rata tes akhir siswa di kelas VII.8 sebagai kelompok eksperimen dan VII.7 sebagai kelompok kontrol.

\section{HASIL}

Hasil penelitian ini berupa LKS berbasis model pembelajaran Group Investigation, yang bertujuan untuk memfasilitasi kemampuan penalaran matematis siswa. LKS ini dikembangkan berdasarkan tahapan penelitian dan pengembangan ADDIE, yaitu :

\section{Tahap Analyze}

Pada tahap analisis, diketahui bahwa kurikulum yang digunakan di SMPN 4 Siak Hulu adalah Kurikulum 2013 revisi tahun 2016. LKS ini dikembangkan bagi siswa kelas VII pada materi segitiga. Siswa SMP tersebut berusia diantara 11 hingga 13 tahun. Model Pembelajaran Group Investigation adalah salah satu tipe model pembelajaran kooperatif yang memiliki titik tekan pada partisipasi dan aktifitas siswa untuk mencari materi atau segala sesuatu mengenai materi pembelajaran yang akan dan merupakan salah satu cerminan dari model pembelajaran saintifik yang diberlakukan pada kurikulum 2013 sekarang ini.

\section{Tahap Design}

Tahap design merupakan tahap merancang LKS matematika berbasis model pembelajaran Group Investigation serta komponen-komponen yang berkaitan dengan LKS tersebut. Berikut diuraikan secara singkat beberapa bagian LKS yang telah dirancang :

\section{Cover}

Cover depan berisi judul, keterangan konsentrasi bahan ajar untuk SMP Kelas VII semester genap, dan identitas dari masing-masing pemegang LKS (nama, kelas, dan asal sekolah). Desain dibuat full colour yang disesuaikan antara warna satu dengan warna yang lainnya dengan tujuan untuk menarik bagi siswa. Desain cover yang dirancang seperti pada gambar berikut. 


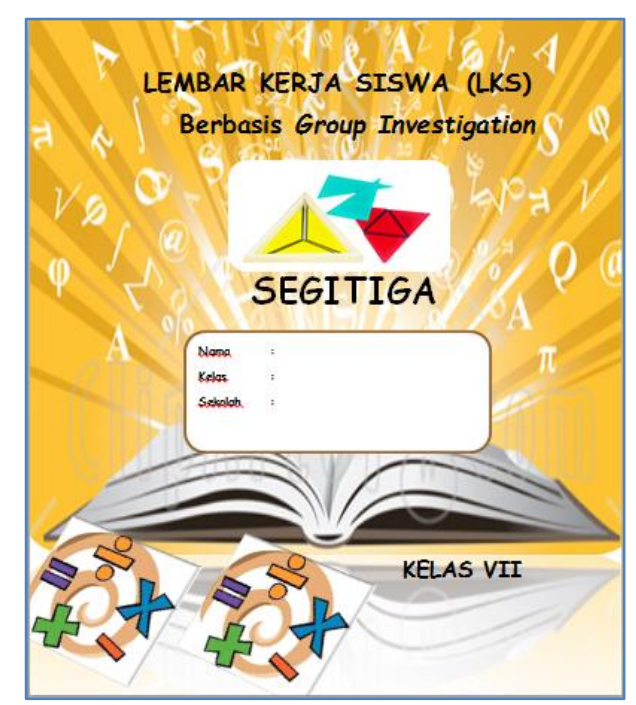

Gambar 1. Desain Cover

\section{Petunjuk Penggunaan}

Di dalam LKS ini diberikan petunjuk penggunaan LKS. Hal ini dimaksudkan agar dapat mengarahkan siswa dalam menggunakan LKS. Adapun petunjuk penggunaan LKS ini adalah :

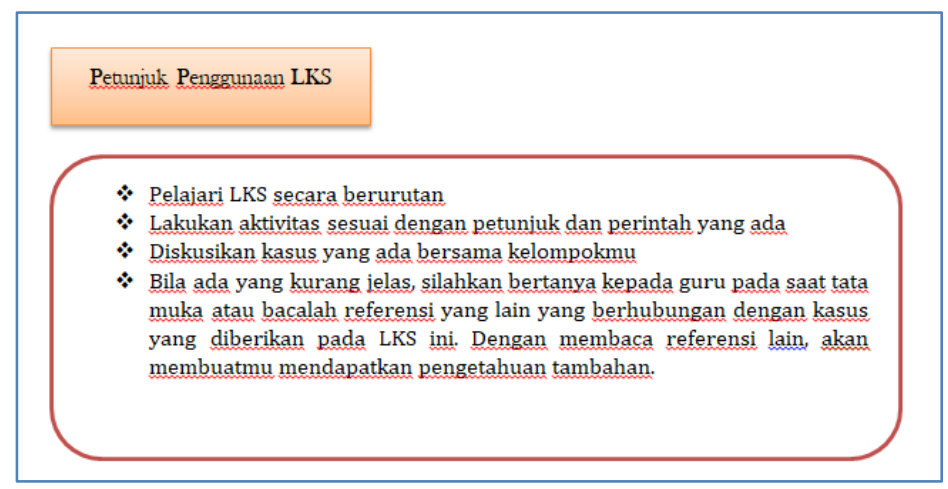

Gambar 2. Petunjuk Penggunaan LKS

\section{Kegiatan Pembelajaran}

Di dalam LKS berbasis model Group Investigation ini termuat kegiatan pembelajaran. Kegiatan pembelajaran mengarahkan siswa untuk mencari informasi secara mandiri dan menggunakan strategi untuk menyelesaikan persoalan yang di berikan di dalam kelompoknya. Berikut ditampilkan salah satu kegiatan pembelajaran yang termuat dalam LKS ini : 

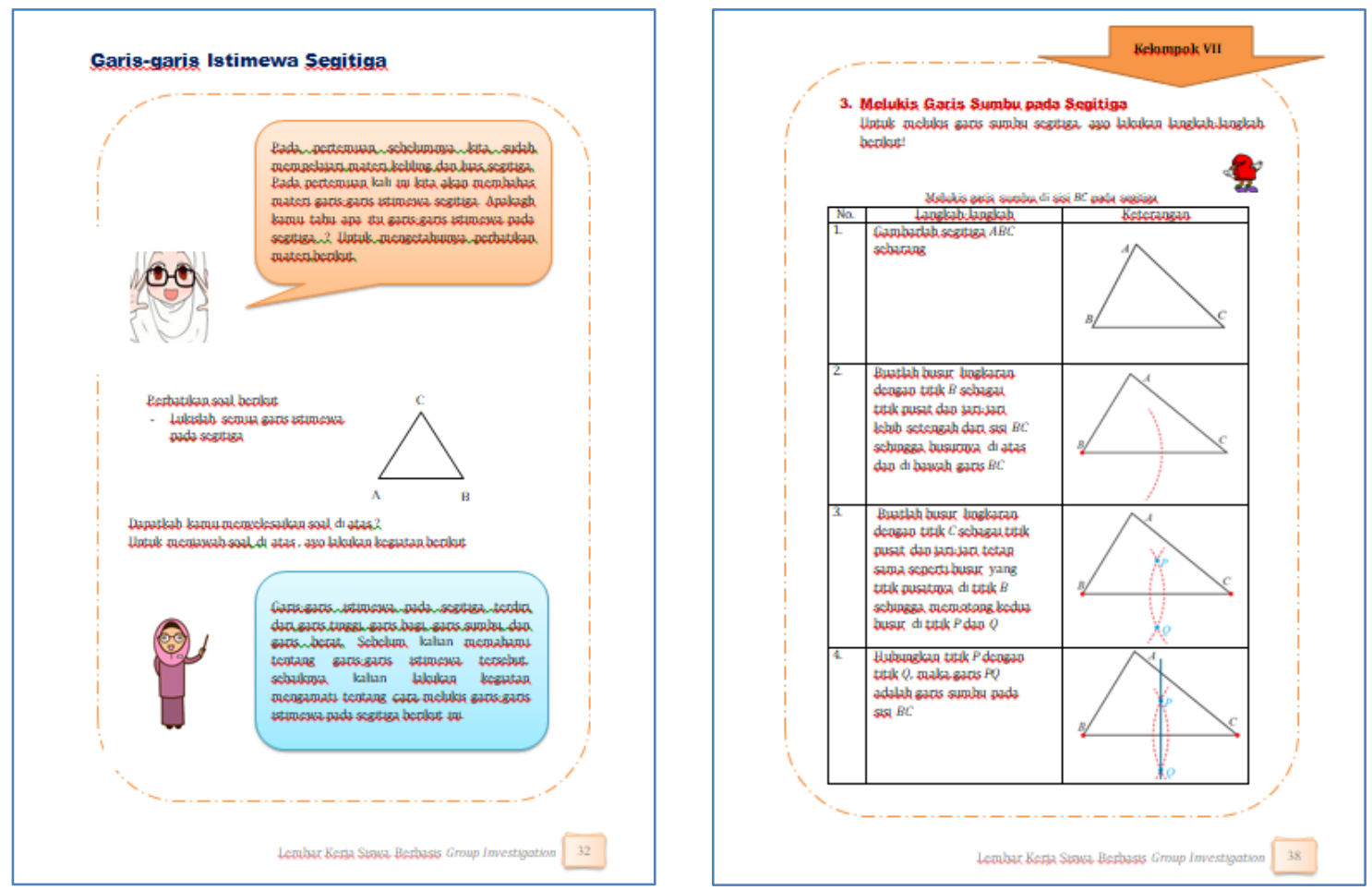

Gambar 3. Desain Kegiatan Pembelajaran

\section{Tahap Development}

Setelah mendesain produk, kemudian produk berupa LKS matematika yang dikembangkan divalidasi oleh validator dari masing-masing ahli. Adapun ahli yang dimksud adalah ahli teknologi pendidikan dan ahli materi pembelajaran dengan menggunakan angket..

Uji Validasi LKS oleh Abli Materi Pembelajaran

Tabel 1. Hasil Uji Validasi Ahli Materi Pembelajaran

\begin{tabular}{clcc}
\hline No & \multicolumn{1}{c}{ Indikator Penilaian } & Nilai Validitas & Kriteria \\
\hline 1 & Kelayakan isi & $85,85 \%$ & Sangat Valid \\
2 & Memuat fase-fase pembelajaran grroup investigation & $86,03 \%$ & Sangat Valid \\
Rata-rata & $85,30 \%$ & Sangat Valid \\
\hline
\end{tabular}

Uji Validasi LKS oleh Abli Teknologi

Tabel 2. Validasi Ahli Teknologi Pendidikan

\begin{tabular}{cccc}
\hline No & \multicolumn{1}{c}{ Indikator Penilaian } & Nilai Validitas & Kriteria \\
\hline 1 & Penggunaan huruf dan tulisan & $83,35 \%$ & Sangat Valid \\
2 & Desain LKS & $81,10 \%$ & Sangat Valid \\
Rata-rata & $82,20 \%$ & Sangat Valid \\
\hline
\end{tabular}

Pada Tabel 1 dan 2 terlihat bahwa untuk persentase keidealan setiap indikator validitas ahli materi pembelajaran maupun ahli teknologi melebihi $80 \%$ sangat valid. Persentase rata-rata validitas LKS dari ahli materi dan ahli teknologi masing-masing adalah 85,30\% dan 82,20\% dengan kategori sangat valid. Secara keseluruhan, uji validitasi terhadap LKS berbasis generative learning adalah 83,75\%. Angka ini menunjukkan bahwa LKS yang dikembangkan telah sesuai valid dari segi materi pembelajaran dan tegnologi pendidikan. 


\section{Tahap Implementation}

Setelah LKS yang dirancang dinyatakan valid, maka LKS diberikan kepada 6 orang siswa yang telah mendapatkan segitiga. Ujicoba ini dilakukan untuk melihat tingkat kepraktisan LKS sebelum diterapkan di dalam pembelajaran. Persentase tingkat kepraktisan LKS berbasis model Group Investigation yang diperoleh adalah $94,83 \%$, artinya LKS ini sangat praktis digunakan dalam pembelajaran. Namun, saran dan masukan dari siswa diperhatikan untuk mendapatkan hasil yang lebih baik.

Selanjutnya, dilakukan pembelajaran menggunakan LKS berbasis Group Investigation di kelas VII.8 pada materi segitiga. Adapun hasil uji kepraktisan adalah sebagai berikut :

\section{Tabel 3. Uji Praktikalitas LKS}

\begin{tabular}{clcl}
\hline No & Indikator Penilaian & Nilai Kepraktisan & Kriteria \\
\hline 1 & Kemenarikan & $94,63 \%$ & Sangat Praktis \\
2 & Perhatian & $95,32 \%$ & Sangat Praktis \\
3 & Ketertarikan & $96,01 \%$ & Sangat Praktis \\
4 & Keterkaitan & $93,52 \%$ & Sangat Praktis \\
5 & Keyakinan & $96,43 \%$ & Sangat Praktis \\
6 & Kepuasan & $95,43 \%$ & Sangat Praktis \\
Rata-rata & $95,20 \%$ & Sangat Praktis \\
\hline
\end{tabular}

Berdasarkan Tabel di atas, persentase praktikalitas dari kelompok terbatas termasuk kategori sangat praktis dengan rata-rata nilai praktikalitas di atas $90 \%$.

\section{Uji Efektivitas LKS}

Efektivitas LKS ini diuji dengan melakukan uji perbandingan rata-rata hasil tes akhir kemampuan penalaran matematis. Rata-rata hasil tes akhir yang dibandingkan adalah rata-ra tes akhir siswa di kelas VII.8 dan kelas VII.7. Dimana siswa kelas VII.8 memperoleh pembelajaran menggunakan LKS berbasis Group Investigation, sedangkan kelas VII.7 memperoleh pembelajaran konvensional. Berikut disajikan statistik deskriptif hasil tes akhir kedua kelas :

Tabel 4. Statistik Deskriptif Hasil Tes Akhir Kemampuan Penalaran Matematis Siswa

\begin{tabular}{ccccc}
\hline Kelompok & Rata-rata & Varians & Skor Maksimun & Skor Minimum \\
\hline Eksperimen (VII.8) & 45,37 & 14,53 & 70 & 19 \\
Kontrol (VII.7) & 36,34 & 14,85 & 70 & 17 \\
Skor Ideal & & & 70 & \\
\hline
\end{tabular}

Tabel di atas menunjukkan bahwa terdapat perbedaan rata-rata hasil tes kemampuan penalaran matematis di kedua kelas. Hasil tes akhir di kelas eksperimen lebih besar 9,03 poin dibanding rata-rata tes akhir di kelas kontrol. Walaupun demikian, perlu diujikan signifikansi perbedaan rata-rata ke dua kelas. Uji perbedaan rata-rata tes akhir kemampuan penalaran matematis siswa dilakukan menggunakan uji-t dengan taraf signifikansi 0,05 .

Hasil perhitungan yang dilakukan menunjukkan bahwa $t_{\text {hitung }}>t_{\text {tabel }}$ yaitu 2,57 $>$ 2,00, artinya terdapat perbedaan kemampuan penalaran matematis antara kelompok eksperimen dan kelompok kontrol. Jika membandingkan rata-rata kedua kelas, maka rata-rata kelas yang menggunakan LKS berbasis Group Investigation lebih baik dibanding kelas yang tidak menggunakan LKS.

\section{Tahap Evaluation}

Proses evaluasi pada penelitian ini tidak dihanya dilakukan di akhir penelitian, namun sejak awal penelititian, yaitu tahap analisis. Evaluasi dilakukan dengan memperhatikan saran dan kritikan yang diberikan para ahli dan siswa. Saran-saran dari validator dan siswa dijadikan bahan revisi. 
Beberapa saran dari validator adalah memperindah desain cover, memperbaiki halaman, penulisan, kepustakaan, menambahkan soal-soal penalaran dan langkah-langkah kegiatan yang harus merujuk pada fase-fase model pembelajaran Group Investigation serta harus mampu mengarahkan siswa untuk bernalar. LKS telah diperbaiki sesuai saran dari validator dan hasil uji praktikalitas.

\section{PEMBAHASAN}

Penelitian ini bertujuan untuk mengembangkan suatu produk bahan ajar/media pembelajaran yang valid, praktis dan efektif. Media yang dikembangkan berupa lembar kerja siswa (LKS) yang merujuk pada fase-fase model pembelajaran Group Investigation. LKS yang dikembangkan telah diuji kevalidan dan kepraktisan serta efektivitasnya untuk memfasilitasi kemampuan penalaran matematis siswa.

Hasil penelitian menunjukkan bahwa LKS berbasis model Group Investigation ini telah valid dan praktis digunakan bagi siswa kelas VII pada materi segitiga. Hasil uji perbedaan rata-rata nilai tes akhir menunjukkan bahwa LKS ini efektif untuk memfasilitasi kemampuan penalaran matematis siswa. Hal ini disebabkan oleh langkah-langkah kegiatan pada LKS ini mengarahkan siswa untuk aktif mencari, mengumpulkan, menganalisis informasi sesuai dengan topik yang mereka pelajari di dalam kelompok. Sebagaimana yang dikatakan oleh Imas (2015:71). bahwa model pembelajaran Group Investigation adalah salah satu tipe model pembelajaran kooperatif yang memiliki titik tekan pada partisipasi dan aktivitas siswa untuk mencari materi atau segala sesuatu mengenai materi pembelajaran yang akan dipelajari. Setiap kelompok bekerja berdasarkan metode investigasi menggunakan LKS yang diberikan (Suprijono, 2012:219). Dengan menggunakan LKS berbasis Group Investigation ini, siswa harus mengidentifikasi topik, mengumpulkan informasi, menganalisis data, berdiskusi, saling bertukar ide untuk menyelesaikan persoalan (Slavin, 2005:218). Tahapan-tahapan tersebut tentunya mengharuskan siswa saling berargumen dan memeriksa kembali kesahihan argumen tersebut. Artinya, LKS berbasis Group Investigation ini membimbing siswa untuk bernalar.

Hasil penelitian ini mendukung hasil penelitian Ana, Fitrihidajati dan Susantini (2010:185) bahwa LKS berbasis Group Investigation mampu melatih siswa untuk merumuskan masalah, memberikan argumen dan melakukan evaluasi. Langkah-langkah kegiatan pembelajaran yang termuat di dalam LKS merujuk pada fase model pembelajaran Group Investigation mampu meningkatkan kemampuan penalaran matematis siswa. Sebagaimana hasil penelitian Linuhung dan Sudarman (2016:59) bahwa kemampuan penalaran matematis siswa yang memperoleh pembelajaran kooperatif tipe Group Investigation lebih tinggi dibanding siswa yang memperoleh pembelajaran konvensional. Hasil penelitian tindakan kelas yang dilakukan oleh Bate'e (2015:37) menyimpulkan bahwa penerapan pembelajaran Group Investigation meningkatkan motivasi dan hasil belajar matematika siswa. Alimuddin (2017:155) menambahkan bahwa siswa yang belajar dengan model pembelajaran kooperatif tipe Group Investigation lebih aktif bertanya dan menaggapi pertanyaan berkaitan dengan topik yang mereka pelajari. Keaktivan siswa dalam pembelajaran berimbas pada meningkatnya hasil belajar matematika mereka.

\section{DAFTAR PUSTAKA}

Ana. N, Fitrihidajati. H dan Susantini, E. 2010. Pengembangan Lembar Kerja Siswa (LKS) Berbasis Pembelajaran Kooperatif Group Investigation (GI) untuk Melatih Keterampilan Berpikir Kritis. Prosiding Seminar Nasional Pendidikan Biologi FKIP UNS, Solo.

Alimuddin, H. 2017. Penerapan Model Pembelajaran Kooperatif Tipe Group Investigation terhadap Hasil Belajar Matematika. Histogram : Jurnal Pendidikan Matematika, 1(2), 143-157. 
Arsyad, A. 2014. Media Pembelajaran Jakarta: Rajawali Pers

Bate'e, A. 2015. Penerapan Model Pembelajaran Kooperatif Tipe Group Investigation untuk Meningkatkan Motivasi dan Hasil Belajar Matematika Siswa SD Negeri 4 Idangogayo. Jurnal Bina Gogik, 2(1), 25-37.

Imas K, dkk. 2015. Ragam Pengembangan Model Pembelajaran. Jakarta : Kata.

Linuhung. N dan Sudarman, S.W. 2016. Pengaruh Pembelajaran Kooperatif Tipe Group Investigation (GI) terhadap Kemampuan Penalaran Matematis Siswa MTs. Jurnal Aksioma, 5(1), 52-60.

Mikrayanti. 2016. Meningkatkan Kemampuan Penalaran Matematis melalui Pembelajaran berbasis Masalah. Suska Journal of Mathematics Education, 2(2), 97-102.

Mulytiningsih, E. 2014. Metode Penelitian Terapan Bidang Pendidikan. Bandung: Alfabeta.

Prastowo, A. 2013. Panduan Kreatif Membuat Bahan Ajar Inovatif. Yogyakarta: Diva Press.

Pribadi, B.A. 2009. Model Desain Sistem Pembelajaran. Jakarta: Dian Rakyat.

Sari. D.P, Yerizon dan ZA.N. 2012. Dampak Pembelajaran Kelompok Investigasi Dalam Belajar Matematika terhadap Kemampuan Penalaran. Jurnal pendidikan Matematika FMIPA-UNP, Padang, 1(1), 40-45.

Slavin, R.E. 2005. Cooperative Learning, Bandung: Nusa Media.

Suprijono, A. 2012. Cooperative Learning Teori dan Aplikasi Paikem. Yogyakarta: Pustaka Pelajar. 